
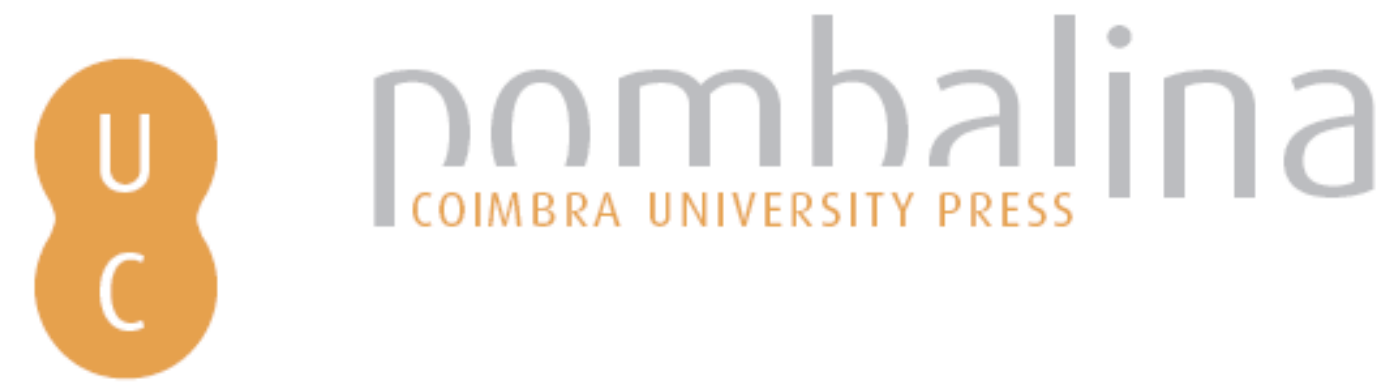

\title{
The large fire of Pedrógão Grande (Portugal) and its impact on structures
}

\author{
Autor(es): \\ Ribeiro, Luís Mário; Rodrigues, André; Lucas, Davi; Viegas, Domingos \\ Xavier
}

Publicado por: Imprensa da Universidade de Coimbra

URL

persistente: URI:http://hdl.handle.net/10316.2/44611

DOI: $\quad$ DOI:https://doi.org/10.14195/978-989-26-16-506_94

Accessed : $\quad$ 26-Apr-2023 14:27:35

A navegação consulta e descarregamento dos títulos inseridos nas Bibliotecas Digitais UC Digitalis, UC Pombalina e UC Impactum, pressupõem a aceitação plena e sem reservas dos Termos e Condições de Uso destas Bibliotecas Digitais, disponíveis em https://digitalis.uc.pt/pt-pt/termos.

Conforme exposto nos referidos Termos e Condições de Uso, o descarregamento de títulos de acesso restrito requer uma licença válida de autorização devendo o utilizador aceder ao(s) documento(s) a partir de um endereço de IP da instituição detentora da supramencionada licença.

Ao utilizador é apenas permitido o descarregamento para uso pessoal, pelo que o emprego do(s) título(s) descarregado(s) para outro fim, designadamente comercial, carece de autorização do respetivo autor ou editor da obra.

Na medida em que todas as obras da UC Digitalis se encontram protegidas pelo Código do Direito de Autor e Direitos Conexos e demais legislação aplicável, toda a cópia, parcial ou total, deste documento, nos casos em que é legalmente admitida, deverá conter ou fazer-se acompanhar por este aviso.

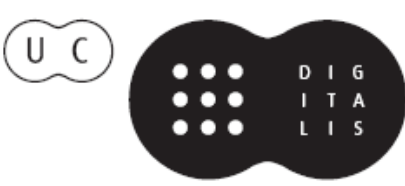




\section{ADVANCES IN}

\section{FOREST FIRE RESEARCH}

\section{8}

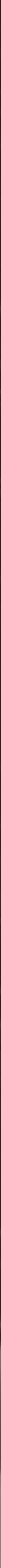




\title{
The large fire of Pedrógão Grande (Portugal) and its impact on structures
}

\author{
Luís Mário Ribeiro*; André Rodrigues; Davi Lucas; Domingos Xavier Viegas \\ Forest Fire Research Centre (CEIF), ADAI-LAETA, University of Coimbra, 3030 - 289 Coimbra, \\ Portugal. \{luis.mario@adai.pt*\}
}

\begin{abstract}
The fire complex that began on 17/6/2017, in Central Portugal, will be for always remembered, not only because of the extensive burned area, but mainly because it caused 65 deaths, more than 200 injured and destroyed hundreds of structures, making it one of the most serious accidents in the country, and one of the worst in Europe. The Forest Fire Research Centre of ADAI (University of Coimbra, PT) performed a detailed analysis and report on this fire complex focused on aspects related to the fire spread and behaviour, the mortal accidents and the fire impact on local communities. The work presented here is related to the latter, i.e., the destruction of property. The greatest impact was observed in the municipalities of Pedrógão Grande, Castanheira de Pera and Figueiró dos Vinhos, where the deaths occurred and where most of the damaged structures were located. This component of structural damage was the subject of an intensive fieldwork, during which we inventoried several aspects related to fire behavior, the structures and their surroundings. During the field work, 1043 structures damaged by fire were identified. They are mostly support structures, such as barracks or storage (38.6\%), but there is a considerable number of damaged dwellings, either permanent $(13.3 \%)$ or temporary $(11.9 \%)$. One of the most important aspects of the study relates to the type and location of structural ignition. More than $60 \%$ of the structures have been ignited due to the deposition of incandescent particles (firebrands) in different weak points. Likewise, more than $60 \%$ of these ignitions occurred on the roofs, mainly because of the vulnerability associated to the structures and materials supporting them. Another relevant factor is the observation of the advanced age of most buildings affected (over 30 years), which may indicate less resistance to the passage of a fire. Nevertheless, and for the Portuguese reality, we can say that buildings are generally safe during the passage of a fire, if themselves and their surroundings are kept in good conditions. The fact that there are people inside can be essential in their defense and resistance to the passage of fire.
\end{abstract}

This paper presents the main results of the assessment of the fire impact on structures, part of a larger work on the Fire Complex of Pedrógão Grande and neighboring municipalities.

Keywords: WUI; impact on structures; large fire

\section{Introduction}

The analysis of the impact of a fire on a given community has inherent the concept of Wildland Urban Interface (WUI), or simply interface. WUI can be simply defined as the space where structures and vegetation coexist in a fire prone environment (BRP, 2008). We must also add the human component (Ribeiro, 2016), because it is mainly people who are affected. This impact can be hard to evaluate, given the difficulty in obtaining measurable data that allows the establishment of gradations of social, economic or even emotional and familiar impact. From a purely structural impact perspective, it becomes more feasible to gather a set of parameters that allow us to estimate how the fire has impacted the community affected.

The way in which the structures in the WUI are damaged by wildfires has received special attention all over the world (e.g. Cohen, 2003; Cohen \& Saveland, 1997; Gollner et al., 2015; Graham et al., 2012; Westhaver, 2016) and efforts have been made by the scientific community, but also the operational and technical ones, in order to understand the ignition mechanisms of the structures and

Advances in Forest Fire Research 2018 - Page 852 
the weaknesses they present to the passage of a wildfire. For instance, Blanchi et al., (2012) carried out an historical analysis on the impact of fire on people and structures across Australia between 1901 and 2011. During this work specific databases were created to allow data harmonization and collection. Inspired by this report, we designed customized geodatabases to allow us the systematic collection of data related to the impacts of the wildfire complex of Pedrógão Grande and neighbouring municipalities, namely on personal accidents resulting in deaths, and on structures damaged. The geodatabases where simple but were designed to collect the maximum amount of detail in the field work, considering the time available to execute the field campaign.

After the extensive field campaign, a detailed analysis of all the collected data was performed, and published in the respective fire report (Viegas et al., 2017). We present here what we believe to be some of the most important results obtained.

\section{Methods}

The analysis of the impact of fire on structures was based on field verification of all buildings damaged by fire, regardless of their use or type. For this purpose, a geodatabase and a geospatial form of simple interpretation and completion were constructed. The database comprised 3 sections: i) description of the structures, for example the type of structure, age, fuel management in the surroundings, condition before and after the fire and usage, among others. The second section was related to describing how the fire affected the structure, namely, the ignition point and the way the structure ignited. The last section was related to fire details (time of arrival, impact on electricity, water, communications) and human behavior (escape/stay and defend, injuries, deaths).

Given the size of the affected area and the time available to carry out the survey and analysis, visiting the entire burned area searching for affected structures would be extremelly hard to accomplish. Therefore, the initial planning comprised the search for initial data sources related to the location of damaged structures. For this, we asked the affected municipalities for information on the structures impacted by the fire in each of them. From the municipalities of Castanheira de Pera, Figueiró dos Vinhos, Penela and Sertã we obtained georeferenced data of the structures that they identified as having been damaged in some way by the fire. Together with Pedrogão Grande, these were the municipalities selected to carry out the fieldwork and the respective analysis. To our knowledge, these surveys were carried out in all municipalities in order to allow applications for reconstruction or rehabilitation support. Later we obtained this data also from the municipality of Góis (27 houses damaged by fire), Pampilhosa da Serra ( 8 dwellings and 20 agricultural wharehouses) and Alvaiázere (10 structures but only a secondary housing), but they were not included in the fieldwork and therefore the analysis. From the municipality of Pedrógão Grande we were not able to obtain this information. However, at the beginning of this work we were invited to join an initiative of Esri Portugal - Sistemas e Informação Geográfica, SA (the official distributor of the North American Esri - Environmental Systems Research Institute, world leader in the technology of Geographic Information Systems), to support the decision in the wildfire of Pedrógão. This initiative was titled "FireHub 2017" and consisted in the creation of a collaborative open data platform (available in June 2017 at http://arcg.is/2rMwc0B). Using this platform, we had access to a set of georeferenced points representing structures allegedly damaged by fire, especially in the municipality of Pedrógão Grande, but with some cases in Castanheira de Pera and Penela. These points were not validated by any entity, so we proceeded with some care to include them in our work.

The impact of the fire was especially noted in the municipalities of Pedrógão Grande, Figueiró dos Vinhos and Castanheira de Pera, so the analysis presented focuses mainly on that region. We also decided to include the neighboring municipalities of Penela and Sertã, since they have suffered considerable damage, albeit in a smaller area. In the municipalities of Góis and Pampilhosa da Serra 
the impact of the fire was lower. It was not possible to extend the study to those two municipalities, due to difficulties related to the execution time of this work.

We were able to gather a substantial set of georeferenced points, which allowed us to schedule the field visits. These points, for a total of 704, represented, for the most part, permanent housings. During the fieldwork, 289 of these points proved to be false. In some cases, there were not even structures in the place indicated by the points, in others the structures had not been damaged by the fire. As we said before, we were interested in all structures damaged by the fire, not only the housings, so during the field work we inventoried another 684 points that were not listed initially. In total, 1388 points were visited, of which 1099 points were initially considered valid. Figure 1 shows the location of all points visited (valid and false) as well as the points not visited, referring to Góis (27), Pampilhosa da Serra (28) and Alvaiázere (10).

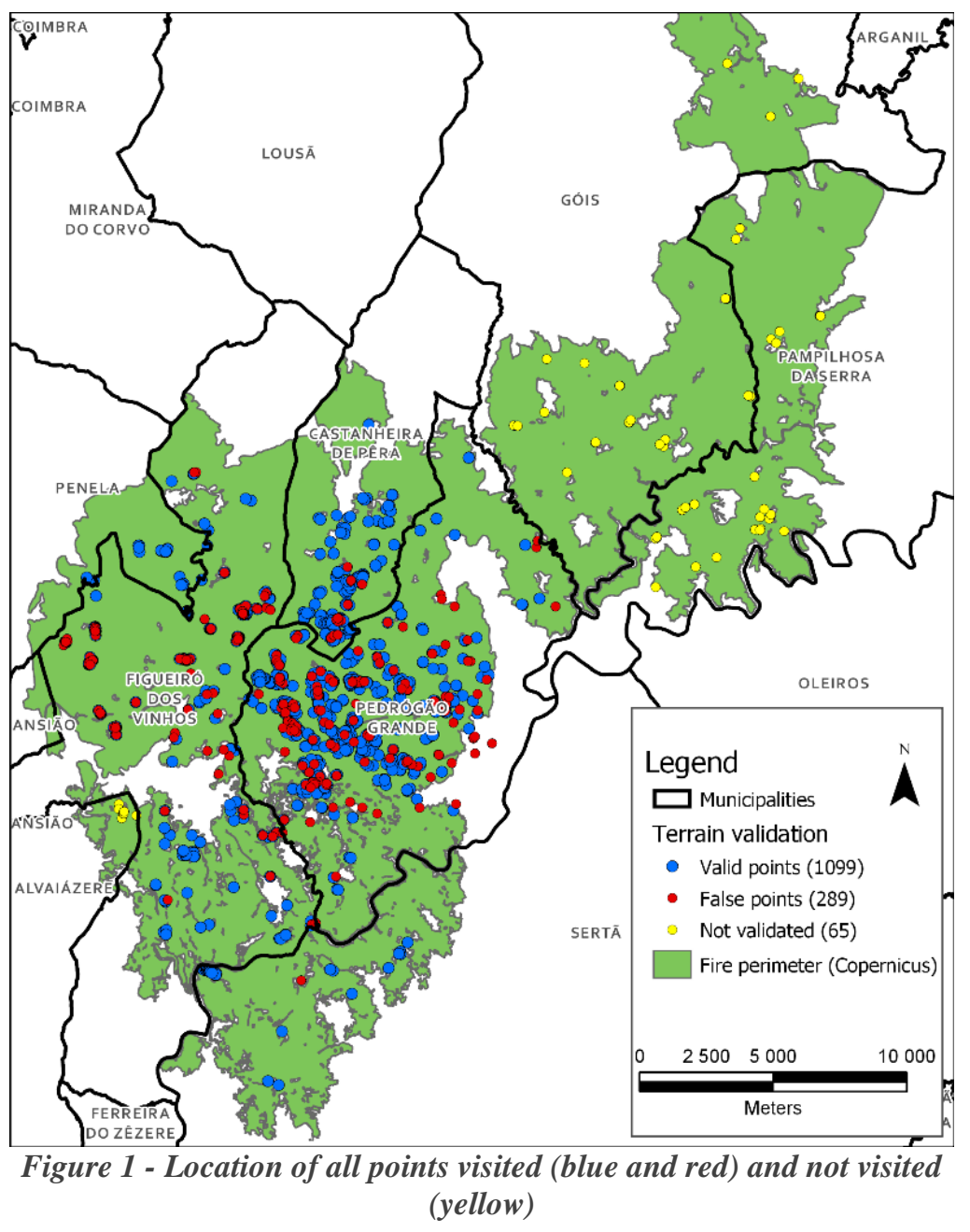

During the field work we encountered several structures in ruins that were already in that state before the fire. Although we started registering them, the number we encountered was so large (and the data gathered not that meaningful) that we decided to leave them out of the analysis. In total, discounting these structures, we finished with 1043 valid points that fulfilled the requirements for analysis.

\section{Results and discussion}

In total, 1043 points (representing affected structures) were considered valid for analysis, from approximately 1400 points visited. The data collected in the field work was treated and analyzed in ArcMap and IBM SPSS Software. Figure 2 shows a density map of damaged structures, or "heatmap". It can be clearly seen the area where the impact was greatest. This area, comprised of five municipalities, also coincides with the region of more extreme fire behavior and to where the 65 victims were found. 


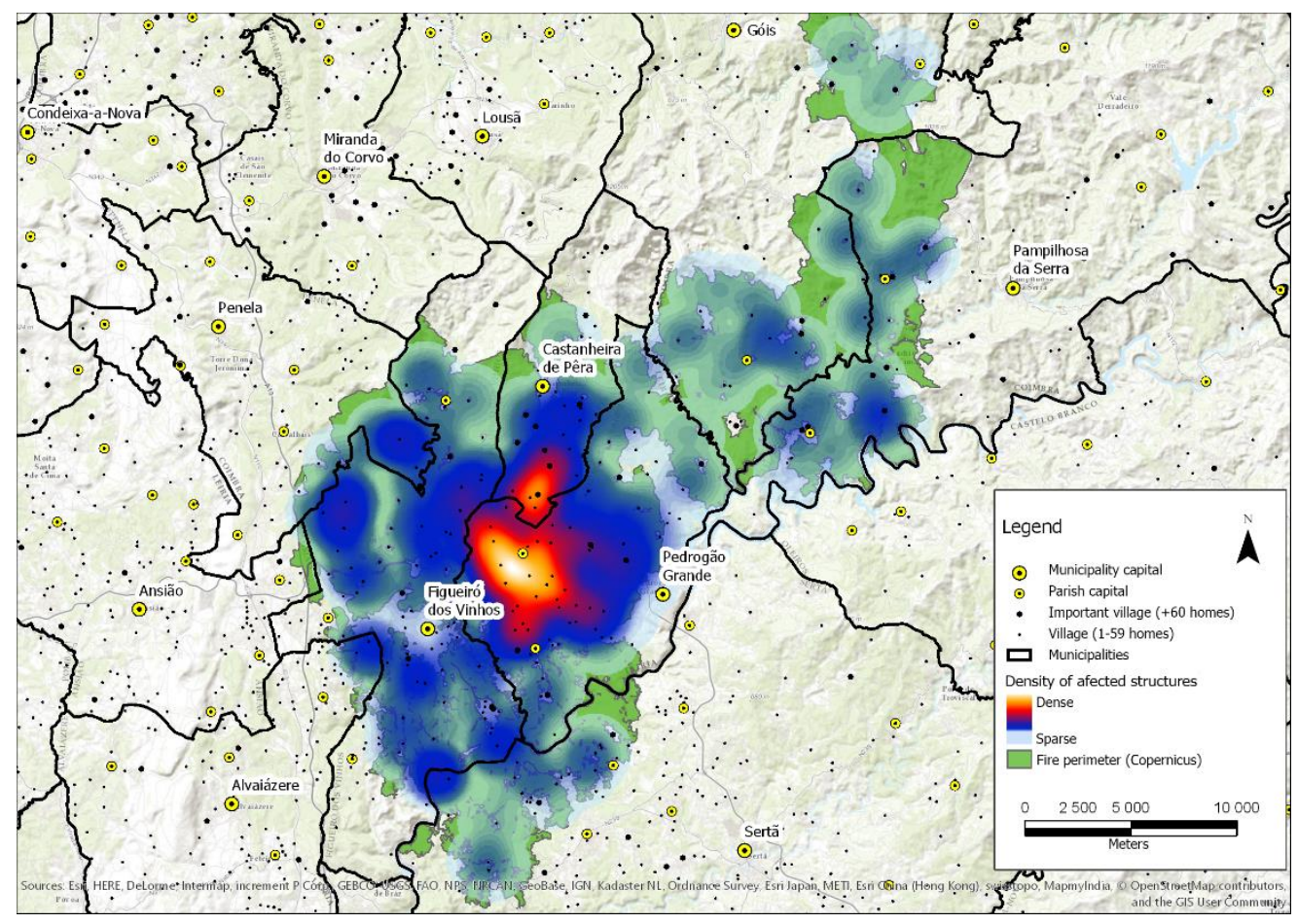

Figure 2 - Heatmap of damaged structures

This was the region chosen for the fieldwork and subsequent analysis. The data collected was treated and analyzed in ArcMap and IBM SPSS Software. Results were grouped in three categories: i) relating to the structure, ii) relating to the surroundings of the structure and iii) relating to the arrival and impact of fire. In the next tables (Tables 1 through 3) we present some of the most relevant results from each of these categories. A most complete set of results can be consulted in Viegas et al., 2017.

Table 1 - Results from the field work related to $i)$ the structure

\begin{tabular}{|c|c|c|c|c|c|c|}
\hline \multirow[b]{2}{*}{ Variable } & & \multicolumn{5}{|c|}{ Structure condition after the fire } \\
\hline & & $\begin{array}{c}\text { Slightly } \\
\text { damaged }\end{array}$ & $\begin{array}{c}\text { Moderately } \\
\text { damaged }\end{array}$ & $\begin{array}{c}\text { Highly } \\
\text { damaged }\end{array}$ & $\begin{array}{c}\text { Totally } \\
\text { destroyed }\end{array}$ & Total \\
\hline \multirow{12}{*}{$\begin{array}{c}\text { Type of } \\
\text { structure }\end{array}$} & Permanent housing & 35 & 17 & 46 & 41 & 139 \\
\hline & Secondary housing & 19 & 9 & 46 & 50 & 124 \\
\hline & Agricultural Warehouse & 1 & 5 & 28 & 40 & 74 \\
\hline & Shed / Storage & 12 & 20 & 179 & 192 & 403 \\
\hline & Garage & 5 & 9 & 22 & 24 & 60 \\
\hline & Comerce facility & 0 & 1 & 0 & 0 & 1 \\
\hline & Industry & 0 & 2 & 5 & 8 & 15 \\
\hline & Uninhabited house & 2 & 4 & 36 & 16 & 58 \\
\hline & Devolute structure & 1 & 3 & 56 & 72 & 132 \\
\hline & Stable & 2 & 1 & 8 & 9 & 20 \\
\hline & Outdoor kitchen & 0 & 2 & 2 & 2 & 6 \\
\hline & Other & 2 & 1 & 4 & 4 & 11 \\
\hline \multirow{3}{*}{$\begin{array}{l}\text { Age of the } \\
\text { structure }\end{array}$} & $<10$ years & 6 & 5 & 2 & 13 & 26 \\
\hline & between 10 and 30 years & 17 & 11 & 26 & 64 & 118 \\
\hline & $>30$ years & 56 & 58 & 399 & 380 & 893 \\
\hline \multirow{5}{*}{$\begin{array}{c}\text { Type of } \\
\text { construction }\end{array}$} & Concrete & 71 & 57 & 195 & 207 & 530 \\
\hline & Stone & 7 & 14 & 222 & 177 & 420 \\
\hline & Wood & 0 & 0 & 0 & 29 & 29 \\
\hline & Metal & 1 & 2 & 14 & 43 & 60 \\
\hline & Other & 0 & 1 & 1 & 1 & 3 \\
\hline
\end{tabular}


Most of the structures affected by the fire are support structures, such as barracks or storage (38.6\%), but there is a considerable number of damaged dwellings, either permanent (13.3\%) or temporary $(11.9 \%)$. The inventoried structures are in general aged, with $86 \%$ being older than 30 years, but they are mainly support structures (only $23 \%$ of affected houses have more than 30 years). Construction in Portugal is mainly of concrete, but in this area we found many old stone structures. Age and building materials are important factors to be taken into account in the structural strength analysis but are themselves dependent on the degree of conservation or maintenance in which the owners maintain them. During the visits it was possible to observe cases of old houses, mainly of schist, recovered and maintained in excellent conditions (mainly by foreigners), while at the same time relatively recent structures were seen, but with a very low degree of maintenance.

Table 2. Results from the field work related to Results from the field work related to ii) the surroundings of the structure

\begin{tabular}{|c|c|c|c|c|c|c|}
\hline \multirow{2}{*}{ Variable } & & \multicolumn{5}{|c|}{ Structure condition after the fire } \\
\hline & & $\begin{array}{l}\text { Slightly } \\
\text { damaged }\end{array}$ & $\begin{array}{c}\text { Moderately } \\
\text { damaged }\end{array}$ & $\begin{array}{c}\text { Highly } \\
\text { damaged }\end{array}$ & $\begin{array}{c}\text { Totally } \\
\text { destroyed }\end{array}$ & Total \\
\hline \multirow{9}{*}{$\begin{array}{l}\text { Land use (COS } \\
\text { 2010, level 2) }\end{array}$} & 1.1 Urban Tissue & 48 & 39 & 181 & 235 & 503 \\
\hline & $\begin{array}{l}1.2 \text { Industry, commerce and } \\
\text { transportation }\end{array}$ & 0 & 1 & 3 & 4 & 8 \\
\hline & $\begin{array}{l}\text { 1.3 Areas of inert extraction, waste } \\
\text { disposal sites and construction sites }\end{array}$ & 0 & 1 & 3 & 1 & 5 \\
\hline & $\begin{array}{c}1.4 \text { Urban green spaces, sports, } \\
\text { cultural and leisure facilities, and } \\
\text { historical areas }\end{array}$ & 0 & 0 & 1 & 1 & 2 \\
\hline & 2.1 Temporary crops & 1 & 2 & 4 & 3 & 10 \\
\hline & 2.2 Permanent crops & 4 & 4 & 19 & 18 & 45 \\
\hline & 2.4 Heterogeneous agricultural areas & 20 & 21 & 152 & 126 & 319 \\
\hline & 3.1 Forests & 4 & 6 & 55 & 58 & 123 \\
\hline & $\begin{array}{l}3.2 \text { Open forests and shrub and } \\
\text { herbaceous vegetation }\end{array}$ & 2 & 0 & 14 & 12 & 28 \\
\hline \multirow{3}{*}{$\begin{array}{c}\text { Fuel } \\
\text { Management }\end{array}$} & Absent & 17 & 20 & 183 & 203 & 423 \\
\hline & Partial & 37 & 40 & 198 & 211 & 486 \\
\hline & Complete & 7 & 8 & 19 & 20 & 54 \\
\hline
\end{tabular}

Analyzing the land use obtained with the level 2 of the official Land Use Map (COS 2010), produced by the Portuguese Direção Geral do Território (General Directorate of Territory), it is possible to verify that most of the impact was on the urban areas $(50 \%)$, specially the urban tissue (48\%). The most affected area after this was the one classified as "heterogeneous agricultural areas" (30\% of the total). The General Directorate of the Territory (Direção-Geral do Território, 2016) describes these areas as "agricultural areas with various types of associations between temporary crops, pastures, permanent crops and natural areas. Includes temporary crops and/or pastures associated with permanent crops, temporary or permanent crops grown under forest cover, areas of temporary crop mosaics, pastures and permanent crops, and landscapes in which crops and pastures are mixed with natural or semi-natural areas. Only about $11 \%$ of damaged structures were within forest areas.

Fuel management is a difficult parameter to assess after the passage of the fire. Nevertheless, and with the help of the local inhabitants, we were able to inventory this aspect in 963 structures. The criteria we used was that, in order to have a "partial" fuel management, at least one of the sides of the structure should have a discontinuity of no less than 3 meters. A "full" fuel management would mean that all 4 sides of the structure had it. Although the results may be statistically not representative, as we did not inventory non-affected houses, they suggest the idea that having "partial" or "absent" fuel 
management may be indifferent to the structure survival. In other words, either fuel management is active on all the surroundings of the structure or its effectiveness may be compromised.

Table 3. Results from the field work related to iii) the arrival and impact of the fire

\begin{tabular}{|c|c|c|c|c|c|c|}
\hline \multirow[b]{2}{*}{ Variable } & & \multicolumn{5}{|c|}{ Structure condition after the fire } \\
\hline & & $\begin{array}{c}\text { Slightly } \\
\text { damaged }\end{array}$ & $\begin{array}{c}\text { Moderately } \\
\text { damaged }\end{array}$ & $\begin{array}{c}\text { Highly } \\
\text { damaged }\end{array}$ & $\begin{array}{c}\text { Totally } \\
\text { destroyed }\end{array}$ & Total \\
\hline \multirow[t]{5}{*}{ Type of ignition } & Embers (spotting) & 27 & 54 & 294 & 261 & 636 \\
\hline & Direct fire impact & 7 & 8 & 91 & 116 & 222 \\
\hline & Materials burning on the vicinity & 7 & 9 & 43 & 74 & 133 \\
\hline & Neighbour structure & 2 & 1 & 3 & 6 & 12 \\
\hline & Damaged but no ignition & 35 & 2 & 1 & 0 & 38 \\
\hline \multirow{8}{*}{$\begin{array}{l}\text { Location of the } \\
\text { ignition }\end{array}$} & Roof & 16 & 36 & 299 & 293 & 644 \\
\hline & Window & 14 & 17 & 70 & 68 & 169 \\
\hline & Door & 4 & 7 & 36 & 28 & 75 \\
\hline & Open structure & 2 & 6 & 13 & 47 & 68 \\
\hline & Wall & 5 & 4 & 0 & 14 & 23 \\
\hline & Ventilation & 0 & 1 & 12 & 6 & 19 \\
\hline & Other & 3 & 1 & 1 & 0 & 5 \\
\hline & Damaged but without ignition & 35 & 2 & 1 & 0 & 38 \\
\hline
\end{tabular}

One of the most important aspects of the study relates to the type and location of structural ignition. More than $60 \%$ of the structures have been ignited due to the deposition of incandescent particles (firebrands) in different weak points. This percentage could even be higher, as 133 ignitions (12\%) were identified as being related to different materials burning in the vicinity of the structure. These were most probably also ignited by embers. More than $60 \%$ of these ignitions occurred on the roofs, mainly because of the vulnerability associated to the structures and materials supporting them.

\section{Conclusion}

The largest impact of this fire complex occurred in the Pedrogão Grande, Castanheira de Pera and Figueiró dos Vinhos municipalities, including small areas in the neighboring municipalities of Penela, Alvaiázere and Sertã. Most damaged structures occurred in this area. These are mainly structures of advanced age (over 30 years), but the majority without being housing. In the fieldwork carried out in the six mentioned counties, we inventoried 263 damaged dwellings (primary and secundary), 91 of which were destroyed. Most ignitions were registered as being originated by firebrands, and mainly affecting roofs and windows. The partial or full absence of fuel management in the surroundings of the houses is a constant in all the burned area. That may explain, in part, the destructive outcome of the Pedrógão fire. Another relevant factor is the observation of the advanced age of most buildings affected (over 30 years), which may indicate less resistance to the passage of a fire. Nevertheless, and for the Portuguese reality, we can say that buildings are generally safe during the passage of a fire, if themselves and their surroundings are kept in good conditions. The fact that there are people inside can even be essential in their defense and resistance to the passage of a wildfire.

\section{Acknowledgements}

The authors wish to acknowledge the support of the Portuguese Government in funding this work and the partial support of project FIREXTR (Prevent and prepare society for extreme fire events: the challenge of seeing the "forest" and not just the "trees"), co-financed by the European Regional 
Development Fund (ERDF) through the COMPETE 2020 - Operational Program Competitiveness and Internationalization (POCI Ref: 16702) ) and national funds by FCT-Foundation for Science and Technology (Proj Ref: PTDC/ATPGEO/0462/2014).

\section{References}

Blanchi, R., Leonard, J., Haynes, K., Opie, K., James, M., Kilinc, M., Dimer de Oliveira, F., \& Van den Honert, R. (2012). Life and house loss database description and analysis Final report. CSIRO, Bushfire CRC report to the Attorney-General's Department. CSIRO EP-129645.

BRP. (2008). The Blue Ribbon Panel on Wildland/Urban Interface Fire. Blue Ribbon Panel. International Code Counci (ICC), USA.

Cohen, J. D. (2003). Preventing Residential Fire Disasters During Wildfires. Em G. Xanthopoulos (Ed.), Proceedings of the International Workshop"Forest Fires in the Wildland-Urban Interface and Rural Areas in Europe: An integral planning and management challenge”, May 15-16. Athens, Greece.

Cohen, J. D., \& Saveland, J. (1997). Structure Ignition Assessment Can Help Reduce Fire Damages in the W-UI. Fire Management Notes, 57(4), 19-23. http://doi.org/http://www.firewise.org/wildfirepreparedness/wui-home-ignition-research/the-jack-cohen-files.aspx?sso=d1d65917-4f03-46dabb5f-0b815f0784ea

Direção-Geral do Território. (2016). Especificações Técnicas da Carta de Uso e Ocupação do Solo (COS) de Portugal Continental para 1995, 2007 e 2010. Relatório Técnico. Direção-Geral do Território. Coordenação: Mário Caetano, Cristina Igreja e Filipe Marcelino.

Gollner, M. J., Hakes, R., Caton, S., \& Kohler, K. (2015). Pathways for Building Fire Spread at the Wildland Urban Interface. Fire Protection Research Foundation.

Graham, R., Finney, M., McHugh, C., Cohen, J., Calkin, D., Stratton, R., Bradshaw, L., \& Nikolov, N. (2012). Fourmile canyon fire findings. USDA Forest Service - General Technical Report RMRSGTR.

Ribeiro, L. M. (2016). Os incêndios na interface urbano-florestal em Portugal: uma análise de diagnóstico. Dissertação para a obtenção do grau de Mestre em Dinâmicas sociais, riscos naturais e tecnológicos. Faculdade de Ciências e Tecnologia da Universidade de Coimbra.

Viegas, D. X., Almeida, M. F., Ribeiro, L. M., Raposo, J., Viegas, M. T., Oliveira, R., Alves, D., Pinto, C., Jorge, H., Rodrigues, A., Lucas, D., Lopes, S., \& Silva, L. F. (2017). O complexo de incêndios de Pedrógão Grande e concelhos limítrofes, iniciado a 17 de junho de 2017. Centro de Estudos sobre Incêndios Florestais (CEI/ADAI/LAETA).

Westhaver, A. (2016). Why some homes survived: Learning from the Fort McMurray wildland/urban interface fire disaster. Toronto, Ontario (Canada): Institute for Catastrophic Loss Reduction Research paper series (56). 